一論 文—

（日.本化学会誌，1984，（4），p.616～623）

(C) 1984 The Chemical Society of Japan

\title{
界面活性なポリ(ビニルアルコール) 誘導体の合成と性質
}

(1983 年 9 月 21 日受理)

\author{
白石 誠吕* ・赤沢敏幸・梶谷浩一
}

ポリ（ビニルアルコール）（PVA）の界面活性をあげる方法として，アセトオキシル基よりもさらに 疎水性の強い基を導入すればよいが，わずかな变成量によって PVA は水に不溶となり，このポリマー の本来有している諸特性がそこなわれる。そこで疎水基として“Versatic acid” のビニルエステル（シ エル社商標 Veova）を用い，親水基として無水マレイン酸またはイタコン酸を使用し，酢酸ビニルと の三元共重合により PVA の機能化を試みた。Veova は酢酸ビニルとの共重合反応性比が $1: 1$ で容 易に導入され，酸モノマーはディレー方式により添加することによって水溶性のポリマーが得られ，水 可溶性に対するVeova と酸モノマーの割合を明らかにした。

このポリマーは予想したように界面活性が高く，また粘度的にも特異な挙動を示し，皮膜は発水性表 面を有する。応用例として酢酸ビニルェマルションの乳化剤として用いると, 高粘度, 低チキソトロピ 一性, 安定性のよいエマルションが得られる。また紙の表面に塗布すると透気度, 吸油度, インキのに じみなどが大きく改善される。これらの原因について,このポリマーの基本物性との関連において推論 した。

\section{1 緒 言}

ポリ(酢酸ビニル)をけん化してポリ（ビニルアルコール）(以 下 PVA と略記する) をつくるとき, 未けん化のアセトキシル 基を残すことにより，さらにはアセトキシル基の分布状態をブ ロック的に不均一化することにより，界面活性が増すことはよく 知られている1。さらに PVA にアセトキシル基より大きな眯水 基を導入することにより, 界面活性をさらに高める試みとして は, 連鎖移動による末端パラフィン基変性 ${ }^{2}$, 長鎖アルキル基を 有するモノマーとの共重合 ${ }^{3)}$,さらには PVA と高級了ルデヒド 類との反応礼などがあげられる。しかしながら界面活性を高める ために十分な量の疎水基を導入しようとすると, 水溶性とか造膜 性など PVA が本来有している基本的な特性が失われてしまらな どの理由で, 十分水溶性であり, かつ界面活性の高いPVA をつ くる試みは, 必ずしもらまくいっていないようにみられる。

著者らは疎水基含有モノマー, 親水基含有モノマーと酢酸ビニ ルとの三元重合を行ない，高い界面活性を有し，かつ水溶性であ るような PVA の機能化を試みた。ここではその PVA の基礎物 性と, その性質を利用した用途物性のいくつかについて述べる。

株式会社クラレ研究所, 710 倉敷市酒津

** 現在 熊本工業大学, 860 熊本市池田

1）林 貞男, 中野千世子, 本山卓彦, 高分子化学, 21,300 (1964).

2）たとえば，小西 尣，石束哲男，高分子化学， 17, 249 (1960).

3）坂戸直行, 地垣哲郎, 保坂 正, 特公 昭 45-18302(1970).

4) 阪田展次, 長谷川 正, 特公 昭 43-16293(1968).

\section{2 実験}

2.1 界面活性化ボリ(ピニルアルコール) の合成 疎水基含有モノマーとして Veova(Veova-10, シェル社商標,<smiles>[R]C([R4])([R4])C(=O)OC=C</smiles>

$\mathrm{R}_{1}, \mathrm{R}_{2}, \mathrm{R}_{3}$ のアルキル基の合計炭素数 8 個の分岐状脂肪酸ビ ルェステル）を用い, 親水基含有モノマーとして無水マレイン酸 またはイタコン酸を用いた。酢酸ビニルとVeova-10は共重合反 応性比はほとんど 1 に等しく5), フィード組成比に応じてランダ ムに共重合する。無水マレイン酸, イタコン酸の場合は重合の進 行に応じて連続的に添加することにより均一な組成のポリマーが 得られる。

一例として酢酸ビニル-Veova-無水マレイン酸の三元共重合に ついて説明する。酢酸ビニルとVeova は前に述べたように共重 合反応性比 $r_{1} \fallingdotseq r_{2} \fallingdotseq 1$ であるので, 酢酸ビニルとVeova の理論 混合物と親水性モノマーの共重合であると考えて差し支えない。 そこで共重合反応性比 (VAc; 酢酸ビニル, MAn; 丝水マレ イン酸） $r_{\mathrm{VAc}}=0.09, r_{\mathrm{MAn}}=0.003$ を採用し，共重合の手法は Hanna $^{6)}$ にしたがった。

かきまぜ機, 還流冷却器, 温度計, 滴下漏斗を備えた $5 l$ 容の 四つロセパラブルフラスコに所定量の酢酸ビニル, Veova, 無水 マレイン酸，メタノールを入れ，窒素を吹き込みながら $59^{\circ} \mathrm{C}$ d

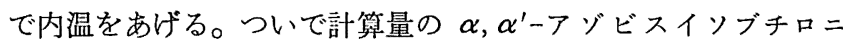

5) J. Bnandrup, E. H. Immergut Editors, "Polymer hand book sec. Ed.", John Wiley \& Sons, New York (1971) p. 125.

6) K. J. Hanna, Ind. Eng. Chem., 49, 208(1957). 
トリル $(\mathrm{AIBN})$ を溶解したメタノール溶液を開始剤として添加 するとともに，所定量の無水マレイン酸を溶解したメタノール溶 液を連続的に滴下しながら，ディレー方式で重合を進める。所定 の重合率に達したならば冷却して重合を停止し，減圧にして未反 応の酢酸ビニルを除去し，このメタノール溶液からポリマーを水 中に再沈眨して精製する。この方法を数回くり返してポリマーを 精製する。乾燥後メタノール溶液から常法でアルカリけん化し， 洗浄，乾燥して三元共重合物を得た。

組成の分析は未けん化の精製ポリマーを用いてアルカリ消費に よってアセトキシル基量を求め, けん化ポリマーの電導度滴定に よりカルボキシル基を定量した。Veova はアルカリによってぬ ったくけん化されないので, 前記測定値からの総和からの差をも って Veova 含有量とした。

\section{2 界面 (表面) 張力}

PVA 水溶液の表面張力および流動パラフィンに対する界面張 力を DuNoüy の表面張力計で測った。

\section{3 乳化重合}

2.3.1重合反応：かきまぜ機，還流冷却器，滴下漏斗をそな えた $2 l$ 容の四つ口丸底セパラブルフラスコに $30 \mathrm{~g}$ (純分) の
PVA， $0.1 \mathrm{~g}$ の $\mathrm{NaHCO}_{3}$ を投入し，水を加えて $529 \mathrm{~g}$ としてか ら煮沸溶解する。内温を $60^{\circ} \mathrm{C}$ に冷却し, 酢酸ビニル $54 \mathrm{ml}$ を添 加し，窒素を吹き込みながら 10 分間かきまぜる。過硫酸アンモ ニウム (APS) の $5 \%$ 水溶液 $32 \mathrm{ml}$ を加え, 重合が開始されたら 酢酸ビニル $376 \mathrm{ml}$ を 1 時間にわたって，内温を $65 \sim 70^{\circ} \mathrm{C}$ にたる ちながら連続的に添加する。添加が終ったら APS の水溶夜 $8 \mathrm{~m} l$ を加えさらに 30 分間重合をつづけたのち冷却する。重合中は窒 素で置換しかきまぜは $300 \mathrm{rpm}$ である。

2.3.2 エマルション物性：エマルションの評価方法はいろい ろあるが，おもな項目について規格に準じて行なった。

a ) 粘度 : Brookfield 型粘度計で $30^{\circ} \mathrm{C}, 10 \mathrm{rpm}, \mathrm{cps}$ で示す。

b) 構造粘性指数 ( $B$ 値)：エマルションのチキソトロピー性 を示す目やすで次式で表わされる。

$$
\begin{aligned}
& B=-\left(\log \eta_{1}-\log \eta_{2}\right) /\left(\log r_{1}-\log r_{2}\right) \\
& \eta_{1} \text { : 回転数 } r_{1} \text { での粘度 }(\mathrm{cps}) \\
& \eta_{2} \text { : 回転数 } r_{2} \text { での粘度 }(\mathrm{cps})
\end{aligned}
$$

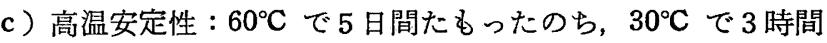
放冷して凝集の有無, 粘度の変化をみる。

d) 低温安定性 : $0^{\circ} \mathrm{C}$ で 20 時間たもったときの粘度 $\left(\eta_{0}\right)$ と，

\begin{tabular}{|c|c|c|c|c|c|c|c|c|c|c|c|}
\hline \multirow[t]{2}{*}{ Run No. } & \multirow{2}{*}{$\begin{array}{c}\mathrm{VAc}^{a)} \\
(\mathrm{g})\end{array}$} & \multirow{2}{*}{$\begin{array}{l}\text { Veova }^{b)} \\
(\mathrm{g})\end{array}$} & \multirow{2}{*}{$\begin{array}{l}\mathrm{AIBN}^{c)} \\
(\mathrm{g})\end{array}$} & & \multicolumn{2}{|c|}{$\mathrm{MAn}^{d)}$ or $\mathrm{IA}^{e)}$} & \multicolumn{2}{|c|}{$\mathrm{MeOH}$} & \multirow{2}{*}{$\begin{array}{l}\text { Temp. } \\
\left({ }^{\circ} \mathrm{C}\right)\end{array}$} & \multirow{2}{*}{$\begin{array}{l}\text { Time } \\
(\mathrm{h})\end{array}$} & \multirow{2}{*}{$\begin{array}{r}\text { Conv. } \\
(\%)\end{array}$} \\
\hline & & & & & $\begin{array}{l}\text { Init. } \\
(\mathrm{g})\end{array}$ & $\begin{array}{c}\text { Delay } \\
(\mathrm{g})\end{array}$ & $\begin{array}{l}\text { Init. } \\
(g)\end{array}$ & $\begin{array}{c}\text { Delay } \\
(\mathrm{g})\end{array}$ & & & \\
\hline 1 & 2700 & 50 & 1.0 & MAn & 0 & 0 & 920 & 0 & 59 & 3.5 & 54.7 \\
\hline 2 & 2700 & 82 & 1. 0 & $" \prime$ & 0 & 0 & 920 & 0 & 59 & 3.4 & 52.0 \\
\hline 3 & 3000 & 138 & 0.45 & $" \prime$ & 0 & 0 & 1000 & 0 & 59 & 5.7 & 36.6 \\
\hline 4 & 2640 & 62 & 2.0 & $\prime \prime$ & 2.8 & 10.9 & 850 & 50 & 59 & 2.5 & 34.2 \\
\hline 5 & 2580 & 122 & 2. 4 & $\prime \prime$ & 2.8 & 11.3 & 850 & 54 & 59 & 2.3 & 35.4 \\
\hline 6 & 2530 & 182 & 2.6 & $" \prime$ & 2.8 & 12.2 & 850 & 60 & 59 & 2.5 & 39.9 \\
\hline 7 & 2100 & 100 & 8.0 & $\prime \prime$ & 2.2 & 18.6 & 1750 & 170 & 59 & 6.0 & 81.4 \\
\hline 8 & 2150 & 51 & 10 & IA & 0.95 & 26.7 & 1800 & 80 & 59 & 4. 0 & 76.3 \\
\hline 9 & 2640 & 62 & 1. 6 & $\prime \prime$ & 0.3 & 5. 4 & 850 & 90 & 59 & 3.0 & 53. 6 \\
\hline 10 & 2900 & 97 & 3.0 & $" \prime$ & 2.7 & 35.0 & 750 & 150 & 59 & 3.0 & 36.8 \\
\hline
\end{tabular}

Table 1 Synthetic conditions of V-PVA

Feed composition

PVA composition

\begin{tabular}{rcccccc} 
Run No. & $\begin{array}{c}\text { Veova } \\
(\mathrm{mol} \%)\end{array}$ & $\begin{array}{c}\text { MAn or IA } \\
(\mathrm{mol} \%)\end{array}$ & $\begin{array}{c}\left.D S^{f}\right) \\
(\mathrm{mol} \%)\end{array}$ & WS $^{g)}$ & $\begin{array}{c}\text { Vis. }^{h)} \\
(\mathrm{cps})\end{array}$ \\
\hline 1 & 0.82 & MAn & 0 & 98.9 & $\bigcirc$ & 42 \\
2 & 1.30 & $\prime \prime$ & 0 & 99.4 & $\times$ & - \\
3 & 2.03 & $\prime \prime$ & 0 & 99.0 & $\times$ & - \\
4 & 1.10 & $\prime \prime$ & 1.10 & 98.4 & $\bigcirc$ & 60 \\
5 & 1.96 & $\prime \prime$ & 0.97 & 98.6 & $\bigcirc$ & 1100 \\
6 & 3.01 & $\prime \prime$ & 1.04 & 98.7 & $\bigcirc$ & 3800 \\
7 & 2.04 & $\prime \prime$ & 1.02 & 98.2 & $\bigcirc$ & 30 \\
8 & 1.02 & IA & 1.00 & 98.1 & $\bigcirc$ & 12 \\
9 & 1.05 & $\prime \prime$ & 0.25 & 99.1 & $\bigcirc$ & 78 \\
10 & 1.42 & $\prime \prime$ & 2.02 & 96.8 & $\bigcirc$ & 140
\end{tabular}

a) Vinyl acetate.

$b$ ) Versatic acid vinyl ester.

c) $\alpha, \alpha^{\prime}$-Azobisisobuty ronitrile.

d) Maleic anhydride.

e) Itaconic acid.

f) Degree of saponification.

g) Water solubility; $\bigcirc$ : Soluble, $\times$ : Insoluble.

h) Viscosity by Brookfield viscometer, $4 \%$ concentration at $20^{\circ} \mathrm{C}$. 


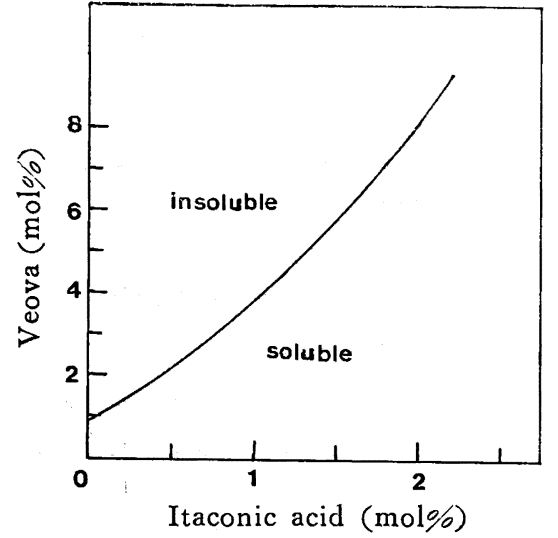

Fig. 1 The relation between substitution degree of Veova and itaconic acid of V-PVA and water solubility

$30^{\circ} \mathrm{C}$ での粘度 $\left(\eta_{30}\right)$ との比をみる。

e ) 凍結安定性 : $-20^{\circ} \mathrm{C}$ に 24 時間たもち, $30^{\circ} \mathrm{C} て ゙ 1$ 時間解 涷してから凝集の有無を判定する。

f）機械安定性：ホモジナイザーで $10000 \mathrm{rpm}, 30$ 分間かきま ぜ後の凝集の有無を判定する。

\section{4 紙物性の測定}

2.4.1 バリャー性能 : 上質紙厚紙 (坪量 $65 \mathrm{~g} / \mathrm{m}^{2}$, 緊度 0.65 , サイズ度 0 秒) にラボサイズプレス（能谷理機(株)）を用い，各 種 PVA 水溶液を塗布した。ドラム型乾燥機で乾燥後 $20^{\circ} \mathrm{C}, 60 \%$ RH の恒温，恒湿の室内で調湿後物性測定に供した。評価は JIS 法に準じた。

ステキヒトサイズ度とは, 水が紙の表面から裏面へしみこんで くるまでの時間(秒)で示されるものでインキのにじみの目やすと なる。透気度とは $615.16 \mathrm{~mm}^{2}$ の面積の紙を $100 \mathrm{ml}$ の空気が通 過するまでの時間(秒)で表わした值である。吸油度とは一定量の 油が紙層中にしみ込んでしまうまでの時間(秒)を示すもので, こ れらは紙のバリャー性を示するっとも一般的な尺度である。

2.4.2 細孔分布, 接触角: 紙の細孔度分布は水銀ポロシメー ターによって測定した。紙表面の原子の状態は ESCA (Du Pont 製）で測った。また接触角はガラス板上の PVA フィルム表面に 水滴を扣とし角度を実测した。

\section{3 結 果}

3.1 基礎物 性

酢酸ビニル-Veova-無水マレイン酸（またはイタコン酸）の三 元共重合結果を表 1 に示す。またこの変性 PVA (以下 V-PVA と略記する）の特徵的な物性について測定した。

3.1 .1 水溶性：釄酸ビニルとVeova を共重合したとき，Veova 量が $0.8 \mathrm{~mol} \%$ 以上になると水溶性がいちじるしく低下し, ついにはまったく溶解しなくなる。親水性モノマーとして無水マ レイン酸またはイタコン酸を共重合すると最初の狙いのように, Veova の含有量が大きくなっても水によく溶ける。 $4 \% \mathrm{PVA}$ 水溶液, $25^{\circ} \mathrm{C}$ で透明度から水溶性を判断したときのVeova とイ タコン酸の量的な限界は図 1 のような関係になる。

3.1 .2 界面 (表面) 張力: PVA 水溶液の表面張力および流動 パラフィンに対する界面張力を测った結果を図 2 に示す。

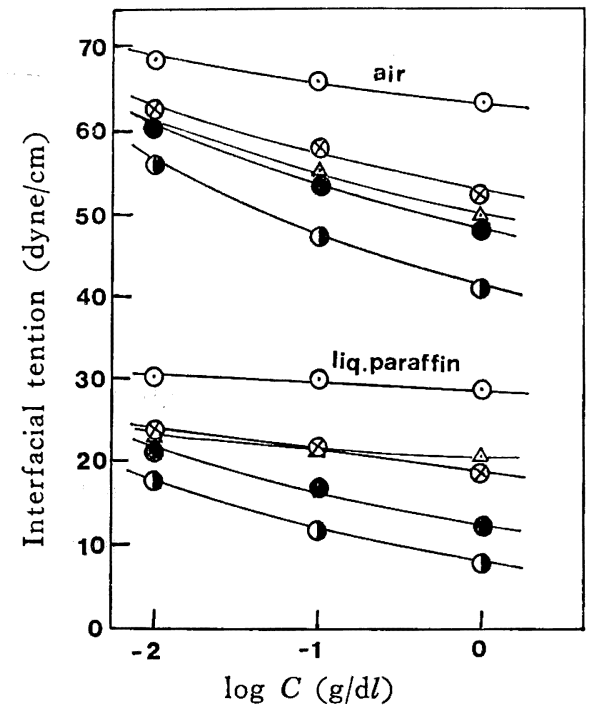

Fig. 2 Concentration dependence on interfacial tention for V-PVA

\begin{tabular}{ccc} 
& Veova $($ mol\%) & Maleic anhydride (mol\%) \\
\hline$\otimes$ & 0.75 & 0 \\
0 & 2.0 & 1.0 \\
0 & 3.0 & 1.0 \\
$\odot$ & ordinary PVA $(P=1750, D S=87.5$ mol\%) \\
\hline
\end{tabular}

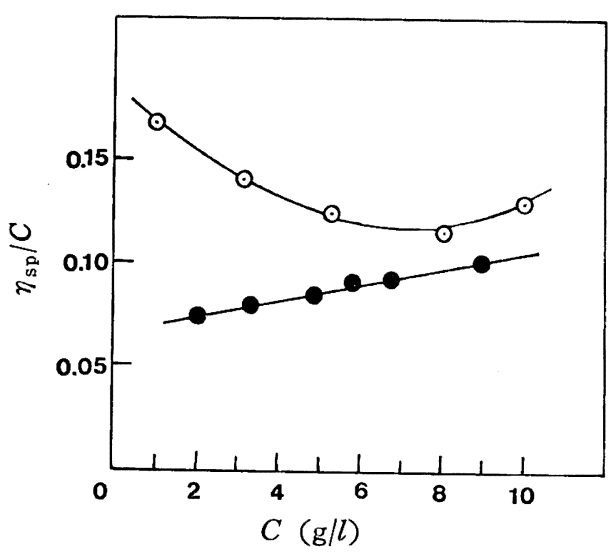

Fig. 3 Concentration dependence on viscosities of dilute V-PVA aqueous solution

V-PVA :

Veova ; 1.05 mol\%, Itaconic acid ; 1.01 mol\% $\bullet$ : Water, $: 0.5 \mathrm{~mol} / l-\mathrm{KI}$

\section{1 .3 水溶液粘度}

（1）希薄水溶液粘度: Veova $1.0 \mathrm{~mol}$, イタコン酸 $1.0 \mathrm{~mol}$ $\%$, けん化度 99.0 mol\%の V-PVA の例を図 3 に示す。 $\eta_{\mathrm{sp}} / C$ $C$ のプロットは水溶液で测定すると, 濃度が低くなるにつれて, $\eta_{\mathrm{sp}} / C$ はかえって大きくなり上に凹の曲線となる。 $0.5 \mathrm{~mol} / l$ ヨ ウ化カリウムの水溶液を用いて測定すると直線となる。

（2）濃厚水溶液粘度：ヨウ化カリウム水溶液の希薄水溶液粘 度から中島式7を用いて求めた重合度の 1750 にほほ等しいVPVA の濃度 $4 \%, 20^{\circ} \mathrm{C}$ での粘度を表 2 に示す。

Veova $2.0 \mathrm{~mol} \%$ ，イタコン酸 $1.0 \mathrm{~mol} \%$ の完全けん化 PVA

7) 中島章夫, 古館勝正, 高分子化学, 6, 460(1949). 
Table 2 The dependence of visocities of V-PVA aqueous solution on degree of substitution $\mathrm{PVA}^{a}$ ) Viscosity $\left.{ }^{b}\right)$

\begin{tabular}{ccr}
$\begin{array}{c}\text { Veova } \\
(\text { mol } \%)\end{array}$ & $\begin{array}{c}\text { Itaconic acid } \\
(\text { mol } \%)\end{array}$ & $(\mathrm{cps})$ \\
\hline 0 & 1.02 & 27 \\
0.51 & 1.00 & 35 \\
1.05 & 1.08 & 55 \\
1.52 & 1.10 & 250 \\
2.11 & 1.06 & 1000 \\
3.08 & 1.03 & 6200
\end{tabular}

a) $\bar{P}_{\mathrm{A}}=1700 \sim 1800$, fully saponified.

b) $4 \%$ Concentration at $20^{\circ} \mathrm{C}$.

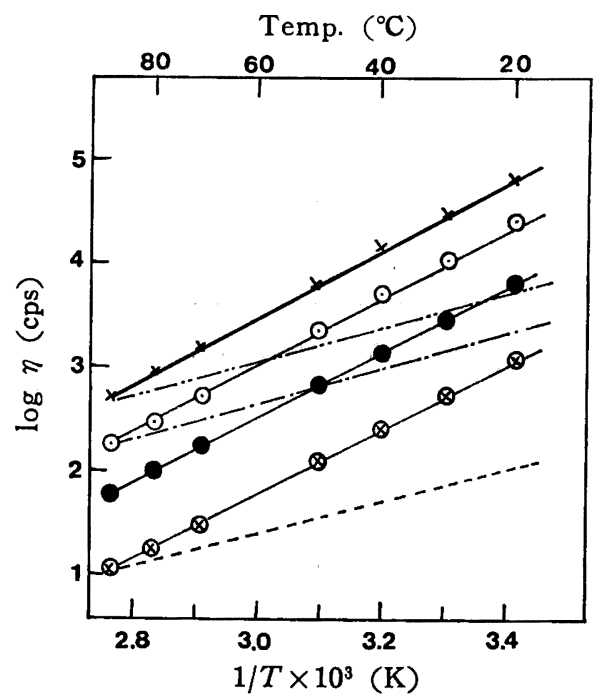

Fig. 4 The temperature and concentration dependence on viscosities of V-PVA aqueous solution

V-PVA :

Veova ; 2.02 mol\%, Itaconic acid ; $1.01 \mathrm{~mol} \%$ Conc. $(\%)$ :

$\times ; 9.8, \bigcirc ; 7.9, \bigcirc ; 6.2, \bigotimes ; 4.0$

Ordinary. PVA $(D S=98.5 \mathrm{~mol} \%)$

$P$ (conc. 10\%) :

$$
\text { -..- ; 2400, —- }- \text {; 1700, }
$$

について, 水溶液粘度-温度-濃度の関係を図 4 に示す。対照とし て重合度 500，1700，2400 の完全けん化 PVA の各 10\% 水溶液 と比較した。

3.1 .4 水滴の接触角 : PVA フィルム表面に対する水滴の接触 角は，普通の完全けん化 PVA で ほぼ $50^{\circ}$ であるが，V-PVA では $80^{\circ} \sim 90^{\circ}$ と大きな接触角を示す（表 3 )。また ESCA によ りフィルム表面を観察した結果を同じく表 3 に示す。

\section{2 応用物性}

基礎物性の測定結果からわかるよらにこの V-PVA は大きな疎 水基を有しながら，かつ水溶性であることから高い界面活性を示 す。これらの特性を酢酸ビニルの乳化重合用の乳化剂に使用した 場合と, 紙の表面に鉒布した二つのケースについて述べる。

3.2.1 乳化剂: PVA の部分けん化物の用途として酢酸ビニル の乳化重合用の乳化剂がある。代表的な処方として APS を用い た前述の重合方法によって得られた結果を表 4 に示した。また各 種評価方法によって求めたェマルション物性のうち, 図 5 に低温
Table 3 Contact angle of water droplet for V-PVA and ordinary PVA films

PVA Contact angle

ESCA

\begin{tabular}{cccc} 
Veova (mol\%) & (degree) & $\overbrace{\mathrm{C}^{*} / \mathrm{O}^{*}}$ & $\mathrm{C}^{*}-\mathrm{H} / \mathrm{C}^{*} \mathrm{O}$ \\
\hline 1 & 86 & - & - \\
2 & 85 & 3.8 & 1.7 \\
Ordinary PVA & 50 & 3.3 & 1.3
\end{tabular}

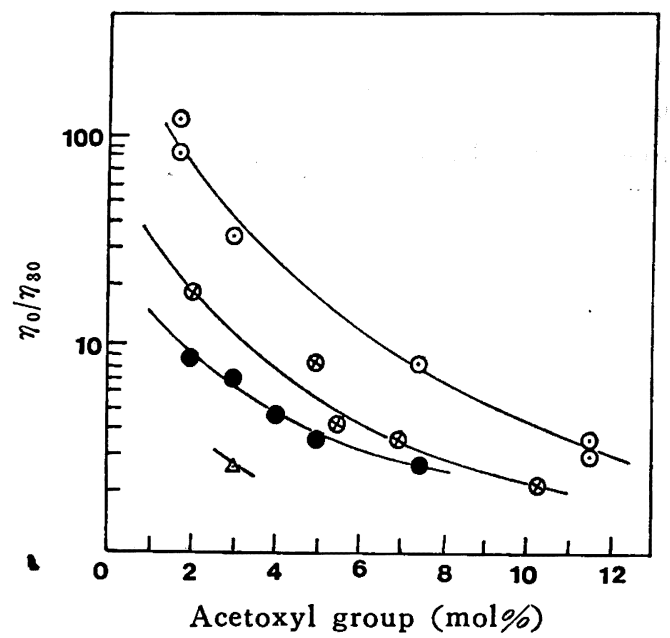

Fig. 5 The relation between $\eta_{0} / \eta_{30}$ and content of acetoxyl groups for V-PVA

$\eta_{0}:$ Viscosity of emulsion at $0^{\circ} \mathrm{C}$

$\eta_{30}$ : Viscosity of emulsion at $30^{\circ} \mathrm{C}$

Veova $(\mathrm{mol} \%)$ :

$\odot ; 0, \bigotimes ; 1.0, \bigcirc ; 1.2, \triangle ; 1.4$

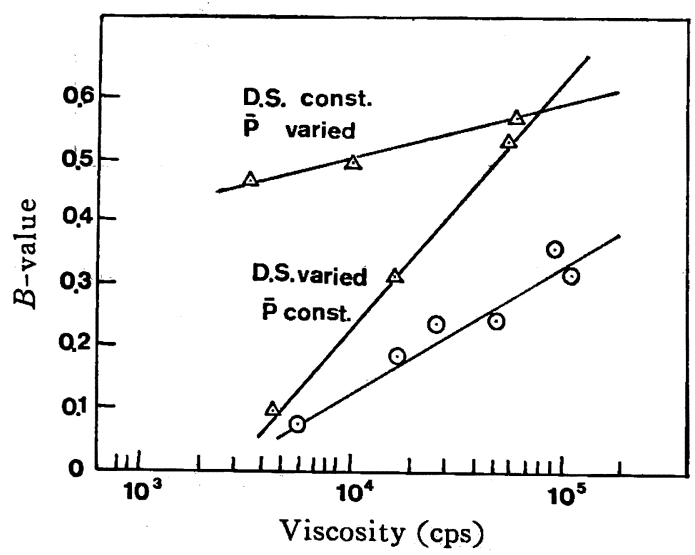

Fig. 6 The relation between $B$-value (structural visco sity index) and viscosity of vinyl acetate emulsion stabilized by various PVA

$$
\text { A : Ordinary PVA, } \odot \text { : V-PVA }
$$

安定性と PVA のけん化度, Veova 变性度との関係を示す。図 6 にェマルションの $B$ 值と粘度について各使用 PVA との関係を, 総合的な評価を表 4 , 図 7 に示す。

\subsection{2 紙加工}

（1）バリヤー性の測定：前述の方法によって上質紙厚紙に対 して行なった各種 V-PVA の塗布量とステキヒトサイズ度の関係 を図 8 に示す。また塗布量 $1.5 \mathrm{~g} / \mathrm{m}^{2}$ の場合のステキヒトサイズ 度, 透気度, 吸油度を表 5 に示す。 
Table 4 Properties of vinyl acetate emulsions

\begin{tabular}{|c|c|c|c|c|c|c|c|c|c|c|}
\hline \multicolumn{4}{|c|}{ PVA } & \multicolumn{6}{|c|}{ Vinyl acetate emulsion } & \\
\hline \multirow[t]{2}{*}{$\widetilde{\overline{P_{\mathrm{A}}^{a}}}$} & \multirow{2}{*}{$\begin{array}{l}\text { Veova } \\
(\operatorname{mol} \%)\end{array}$} & \multirow{2}{*}{$\begin{array}{c}\left.\mathrm{IA}^{b}\right) \\
(\operatorname{mol} \%)\end{array}$} & \multirow{2}{*}{$\begin{array}{c}\left.D S^{c}\right) \\
(\operatorname{mol} \%)\end{array}$} & \multirow{2}{*}{$\begin{array}{l}\mathrm{TS}^{d)} \\
(\%)\end{array}$} & \multirow{2}{*}{$\begin{array}{l}\text { Vis. }^{e)} \\
\text { (cps) }\end{array}$} & \multirow[t]{2}{*}{$\mathrm{B}^{f)}$} & \multicolumn{4}{|c|}{ Stability } \\
\hline & & & & & & & $\begin{array}{l}\text { High } \\
\text { temp. }\end{array}$ & $\begin{array}{l}\text { Low } \\
\text { temp. }\end{array}$ & Freez. $\left.{ }^{g}\right)$ & Mech. $h)$ \\
\hline 1800 & 1. 08 & 2.00 & 98.1 & 48. 1 & 15000 & 0.19 & 0 & 0 & 0 & 0 \\
\hline 1700 & 1.25 & 1.02 & 98.2 & 48.8 & 86000 & 0.33 & 0 & 0 & 0 & 0 \\
\hline 1750 & 0 & 0 & 98.5 & 47.5 & 2600 & 0.06 & $\triangle$ & $x$ & $\times$ & 0 \\
\hline 550 & 0 & 0 & 98.5 & 48.7 & 700 & 0.10 & $\vec{\Delta}$ & $x$ & $x$ & 0 \\
\hline 1750 & 0 & 0 & 87.5 & 47. 9 & 34000 & 0.55 & $\overline{0}$ & 0 & 0 & 0 \\
\hline 550 & 0 & 0 & 88.0 & 47. 7 & 1500 & 0.38 & 0 & $\triangle$ & $x$ & 0 \\
\hline
\end{tabular}

$O$ : Good, $\triangle:$ A little good, $x:$ Bad.

a) Degree of polymerization.

b) Itaconic acid.

c) Degree of saponification.

d) Total solid content.

e) Viscosity at $30^{\circ} \mathrm{C}$ (Brookfield viscometer).

f) Structural viscosity index.

g) Freeze thaw stability.

h) Mechanical stability.

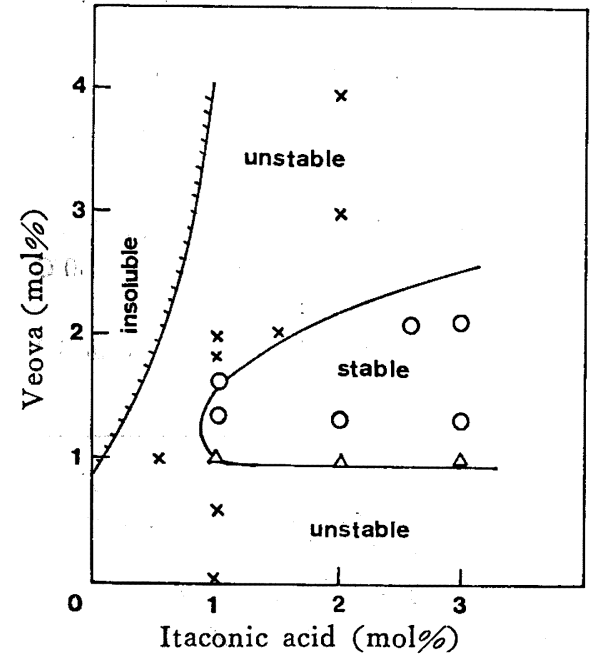

Fig. 7 The influence of substitution degrees of V-PVA on stability of vinyl acetate emulsions

$$
O: \text { Stable, } x: \text { Unstable }
$$

（2） ESCA による測定：表面に塗布されたPVA の状態をみ るために，定性用汇紙に PVA を塗りC*に注目して ESCA を測 定した。結果を図 9 に示す。さらにモデル実験としてガラス板上 に所定の厚さになるように PVA 水溶液を塗り, 乾燥後 $\mathrm{Si} / \mathrm{C}$ の 原子比を測定した。結果を図 10 に示す。

（3）膜厚と接触角：ガラス板上に PVA 水溶液を鉒布した厚 さの暴なった PVA 皮膜に対する水滴の接触角を図 11 に示す。

（4）細孔分布：バリャー性能の測定に用いた塗布紙の細孔分 布を図 12 に示す。

\section{4 考察}

Veova を多く導入してその蹯水基による界面活性を高めるた めに漞水性モノマーと酢酸ビニルの三元共重合による方法で，水 溶性を保持させながら各種物性との対応関係を調べた。まず基礎 物性について考察する。

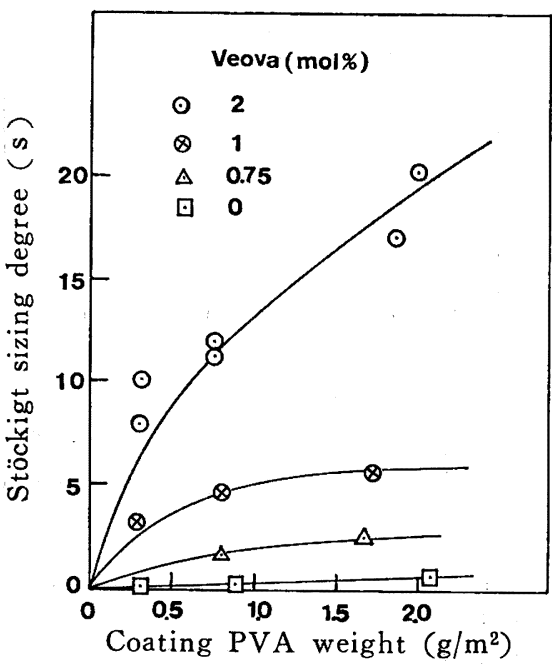

Fig. 8 The relation between Stöckigt sizing degree and coating weight for V-PVA

Table 5 Barrier properties of paper coated with VPVA (coating weight $1.5 \mathrm{~g} / \mathrm{m}^{2}$ )

\begin{tabular}{lrrr}
$\begin{array}{c}\text { PVA } \\
\text { Veova } \\
(\text { mol } \%)\end{array}$ & $\begin{array}{c}\text { Stöckigt sizing } \\
\text { degree } \\
(\mathrm{s})\end{array}$ & $\begin{array}{c}\text { Air } \\
\text { permeability } \\
(\mathrm{s})\end{array}$ & $\begin{array}{c}\text { Oil } \\
\text { absorbability } \\
(\mathrm{s})\end{array}$ \\
\hline 0 & 0 & 75 & 33 \\
0.5 & - & 400 & - \\
1.02 & 4 & 800 & 220 \\
1.51 & 10 & - & - \\
2.03 & 16 & 2100 & 1100 \\
Starch & 0 & 43 & 11 \\
Raw & 0 & 42 & 10 \\
paper & & &
\end{tabular}

\section{1 基礎物性}

さきに述べたように PVA に大きな柾水基を導入して，界面活 性を高める方法はいろいろあるが，いずれもその導入量と水溶性 の関係に限界があり，十分な量の導入ができない。Veova もと 


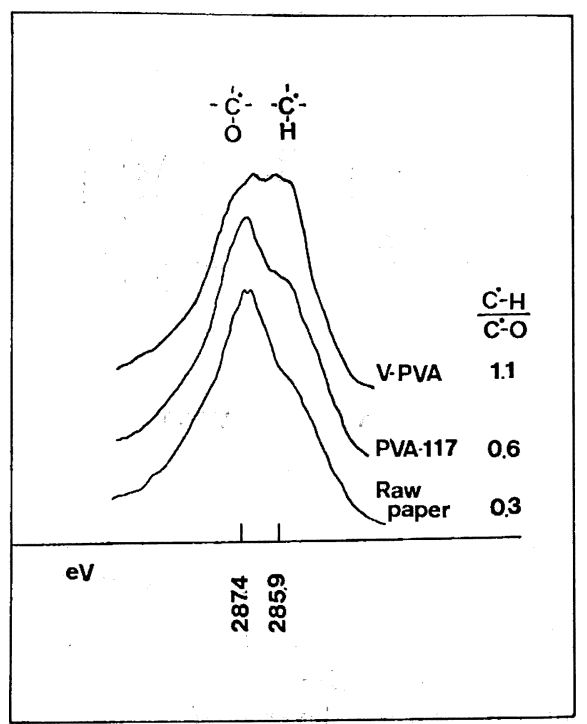

Fig. 9 ESCA of coated paper without or with PVA V-PVA :

Veova ; $2.0 \mathrm{~mol} \%$, Itaconic acid ; 1.0 mol\% PVA-117 :

Ordinary PVA, $P=1750, D S=98.5 \mathrm{~mol} \%$

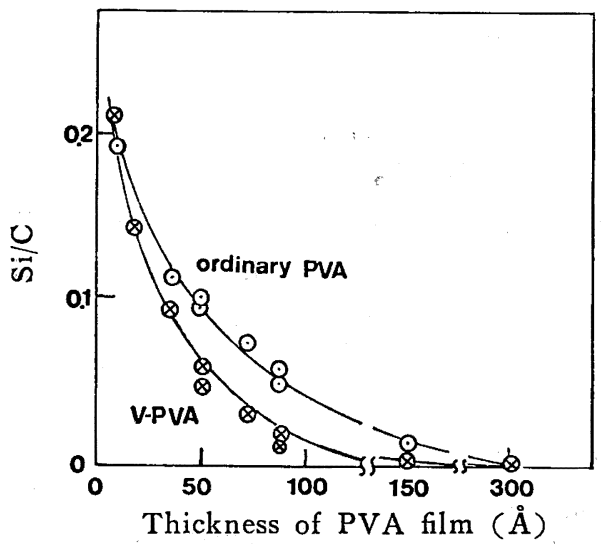

Fig. 10 Thickness dependence on $\mathrm{Si} / \mathrm{C}$ value observed by ESCA for V-PVA and ordinary PVA films on glass plate

V-PVA :

Veova ; 2.0 mol\%, Itaconic acid ; $1.0 \mathrm{~mol} \%$ Ordinary PVA :

$P=1750, D S=98.5 \mathrm{~mol} \%$

の例外ではなくたかだか $0.8 \mathrm{~mol} \%$ が限度であった。前に述べた ように酢酸ビニルとVeova の共重合反応性比はほぼ 1：1 であ るから,この混合物を一つのモノマーと考光, 親水性モノマー, （イタコン酸または無水マレイン酸）との共重合反応を行なえば, Veova とイタコン酸との割合を適当に調節することが可能であ る。重合反応はディレー方式を採用することによって目的とする 三元共重合組成物が得られる。水溶性の範囲は図 1 に示すように イタコン酸の場合, Veova $4 \mathrm{~mol}$ に対しほぼイタコン酸 $1 \mathrm{~mol}$ あたりである。

水溶液の希薄粘度はカルボキシル基が共存するため, 当然典型 的な高分子電解質としての举動を示す（図 3 )。また表 2 に示す ように濃厚溶液の粘度はVeova 量の増加とともに急激に高くな

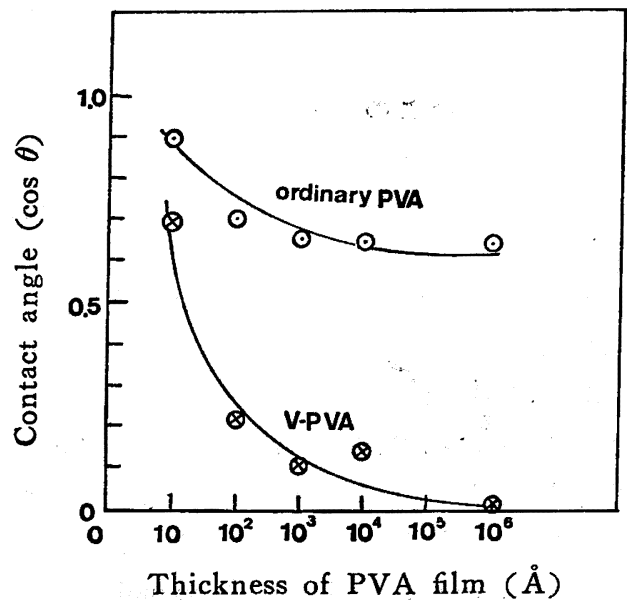

Fig. 11 Thickness dependence on contact angle of water droplet for V-PVA and ordinary PVA films V-PVA :

Veova ; 2.0 mol\%, Itaconic acid; 1.0 mol\% Ordinary PVA :

$P=1750, D S=98.5 \mathrm{~mol} \%$

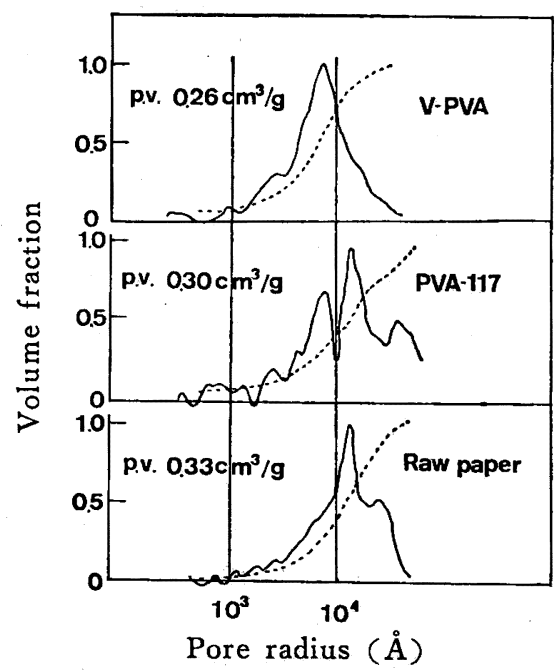

Fig. 12 The porosity of coated papers without or with PVA

V-PVA :

Veova ; $2.0 \mathrm{~mol} \%$, Itaconic acid ; $1.0 \mathrm{~mol} \%$ PVA-117 :

Ordinary PVA, $P=1750, D S=98.5 \mathrm{~mol} \%$

P. V. : Pore volume

る。また粘度一温度一濃度の関係も普通の未変性 PVA にくらべて 異常に高い依存性を示す（図 4)。尊断速度依存性もまた大きい。 この原因はVeova の大きな分子構造とその強い蹯水性のた め, める程度の量の導入により蹯水基間に強い分子間凝集力が作 用して橋かけ構造的なものをつくるか，あるいはミセル構造的な ものをつくり，見かけの分子量が增大するためであろうと考えら れる。

界面活性については予想したように強い活性を示し，図 2 に示 すように空気，流動パラフィンに対しては Veova 2 mol\% (篤 水マレイン酸 $1.0 \mathrm{~mol} \%$ ) 変性の完全けえ化 PVA でも，なお普 通のけん化度 $88 \mathrm{~mol} \%$ の部分けん化 PVA よりる高い界面活性 
を示す。さらにこの変性 PVA のフィルムの接触角は表 3 に示し たように，普通の PVA が $50^{\circ}$ であるのに対し $80^{\circ} \sim 90^{\circ}$ と異常 に大きな值を示す。またこのフィルムを ESCA で表面状態を調 べると， $\mathrm{C}^{*} / \mathrm{O}^{*}$ の原子の割合, およびHの結合した C*とOの結 合した $C^{*}$ との割合 $\mathrm{C}^{*}-\mathrm{H} / \mathrm{C}^{*}-\mathrm{O}$ がいずれも未変性の普通の PVA にくらべて高い值を示している。このことは蹯水基が表面により 多く集っていることを示しており，接触角が異常に高い值となる ことを裏付けている。

\section{2 応用物性}

4.2.1 エマルション: PVA を酢酸ビニルの乳化重合時の乳 化剤として使用するときPVA の性質によって，ェマルションの 物性が大きく変わることはよく知られている。たとえば高温, 低 温, 凍結安定性については, けん化度 $88 \mathrm{~mol} \%$ の部分けん化 PVA がよいとされ，完全けん化物ではむずかしいといわれてい る。この三元共重合した V-PVA では完全けん化物であっても， Veova がある程度導入されると，表 4 に示したように安定性は 向上する。しかし疎水基と親水基のバランスが大切なようであ る。低温安定性についてはVeova を導入しない普通の PVA の 場合（けん化度 $98.5 \mathrm{~mol} \%$ ) では， $\eta_{0} / \eta_{30}$ は 100 近くにまであ るが, Veovaを $1.4 \mathrm{~mol} \%$ 導入することによりたかだか $3 〜 4$ まで減少する。小さな疎水基（アセトキシル基）では多くの量が 必要であるが, Veova のような大きな疎水基では, 少量の導入 で十分低温安定性は向上することがわかる（図 5 )。

またエマルションの流動性については, Veova 量と重合度を かえた V-PVA を用いて, 構造粘性指数 ( $B$ 值) と粘度との関係 を図 6 に示した。この $B$ 値はエマルションのチキソトロピー性を 示す数值で, エマルション粒子表面の水和層の厚みや, 性質によ って左右されるといわれている8。末変性の一般の PVA ではけ ん化度, 重合度ともにB值に影響し, 図にみられるよらにエマル ション粘度が低いにもかかわらず, 構造粘性すなわらチキソトロ ピー性は大きい。しかるにV-PVA ではエマルション粘度は高い にもかかわらず $B$ 值は小さい。いいかえると高粘度-低チキソト ロピー性のエマルションが得られる。

従来のエマルションとの相違の理由については詳しくはわから ないが，一応つぎのよらに考えられる。酢酸ビニルェマルション に対する PVA の吸着, 安定化の機構については議論のあるとこ ろであるが，図 13 に示すようにこれまでの部分けん化 PVA の アセトキシル基は蹯水性があまり強くないため, 十分な吸着能を 出すためには多くの量が必要である。したがって柾水基グループ 間の間隔は短いものとなり, エマルションに吸着して形成するル ープ層によって生ずる水和層はあまり厚いものではないであろ 5 。

それに対して V-PVA の眯水基は数は多くないが䟱水性が強い ため, エマルションの粒子表面にしっかり吸着され，しかも柾水 基間の間隔は長く, 長いループによって厚い水和層を形成するた めに, ェマルションの安定性や粘珄など, 従来のものと違った特 性が現われているのではないかと思われるが，この点に関しては さらに㭘討する必要があろう。

4.2.2 紙加エ：インキのにじみの目やすとなるステキヒトサ イズ度や透気度, 吸油度などが V-PVAを紙の表面に少量塗布す ることにより，未変性 PVAにくらべて大幅に向上することは表

8) M. Shiraishi, Br. Polym. J., 2, 135(1970).

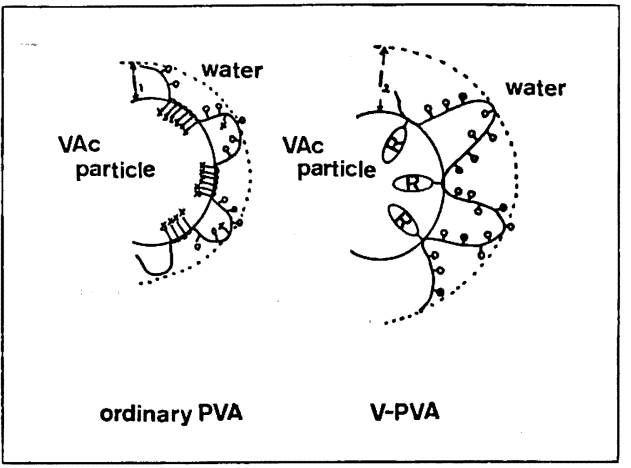

Fig. 13 Schematic diagram of vinyl acetate (VAc) monomer particle stbilized with ordinary PVA (partly hydrolyzed PVA) and V-PVA

$\times-$ : $\mathrm{OCOCH}_{3}$ group, $\mathrm{O}-\mathrm{OH}$ group,

(R)-: Veova group, -: $\mathrm{COOH}$ group

$l$ : Depth of hydrated layer $l_{2}>l_{1}$

5 に示したと拈りである。このバリヤー性発現の作用機構につい て考えてみる。

（1） ESCAによる測定および接触角：図 9 に示したように, 定性用汇紙に PVAを塗布し C*に注目して ESCA を測定する と, PVA の-C*H のピークが $285.9 \mathrm{eV}$ にみられるが, 無塗布で は-C*O に基づく $287.4 \mathrm{eV}$ のピークがほとんどである。V-PVA では $285.9 \mathrm{eV}$ のピークがさらに增大し， $-C^{*} \mathrm{H} /-\mathrm{C}^{*} \mathrm{O}$ の比は通 常の PVA にくらべて大きく, 塗布量は同一でも紙上での PVA の分布状態に差がみられる。

さらにガラス板上に塗布した PVA の Si/C の原子比の測定結 果を図 10 に示したが, $150 \AA$ をこえる皮膜厚さではCがほとん どでSi は検出されない。膜の厚さが薄くなるにつれて Si が検出 されるよらになり，また Si/C の比も大きくなってゆく。しかし 同一厚さでも V-PVA の方が Si/C の比が小さい。これはV-PVA の方が表面をより広くおおっていることを意味しており，造膜性 がよいと推定される。

またガラス板上の厚さの異なった PVA 皮膜に対する水滴の接 触角を図 11 に示したが，V-PVA の方がはるかに大きく，100 Åの厚さでも大きな值を示している。これは造膜性のよいこと と，表面に眯水基が集まっていることを示している。

（2）細孔分布：図 12 の細孔分布測定の結果によると, PVA117 (重合度 1750, けん化度 $98.5 \mathrm{~mol} \%$ ) を塗布した紙より, V-PVA の方が細孔分布は小さい方へシフトしており, Pore Volume の娍少む大きい。ここにはあげないが電子顕微鏡によって も紙の繊維間に PVA 薄膜の形成が認められる。

V-PVA を紙に塗布した場合のいちじるしいバリアー性の向上 は，上述のように ESCA による表面の状態，接触角，細孔分布 の測定值などにより裏付けられたが，1.0〜2.0 g/m² の PVA が

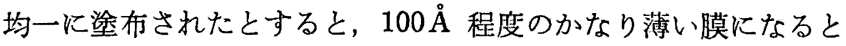
考えられる。これら相違の理由について詳しく不明であるが，皮 膜形式の過程がことなるためと考えられる。すなわち V-PVAの 水溶液が蒸発，濃縮し皮膜を形成するさい，大さな分子棈造を有 する疎水性基のためにポリマーが内部可塑化され造膜性が向上 し, 紙の繊維一緘維間に薄膜を形成しやすい。このために細孔分 布は小さい方へシフトし，各種のバリヤー珄能が向上する。さら に皮膜自身疎水基が表面に集まっているため発水性が高くなり， 
ステキヒトサイズ度などインキのにじみに対しても効果があるも のと考学れる。

\section{5 結 論}

PVA の界面活性を従来の部分けん化 PVA よりさらにあげる ために, アセトキシル基よりも疎水性のより強い基を導入するこ とが考えられるが, 少量の変成によって水不溶性となり PVA 本 来の諸性質がそこなわ机るそこでここでは柾水基として“Versatic acid”のビニルェステル（シェル社商標 Veova）を用い, 然水マレイン酸またはイタコン酸の酸モノマーと, 酢酸ビニルの 三元共重合を行なった。酢酸ビニルと Veova の共重合反応性比 はほとんど 1:1 であるので, この混合物を一つのモノマーと考 点酸モノマーとの共重合を行なえば，変成量の調節は比較的容易 であった。

Veova と酸モノマーはモル比にして 4:1 程度でよく溶ける。 基礎物性としては予想したように，この PVA は界面活性が高く
表面張力の低下がいちじるしい。また希薄水溶液では高分子電解 質的挙動を示し, 濃厚溶液では Veova 量の増大とともに粘度は 指数的に大きくなり，温度，濃度，剪断速度の依存性が大きい。 また皮膜は発水性表面を有する。

これらの基跾物性を利用してVAc ェマルションの乳化剂に用 いると, 高粘度一低チキソトロピー性一高安定性のエマルションが えられる。また紙に少量塗布するとインキのにじや，透気度， 吸油度などの紙のバリヤー性能が改善される。この原因は PVA 水溶液が蒸発, 濃縮して皮膜を形成するさいに, 大きな分子棈造 を有する疎水性基のために，ポリマーが内部可塑化されて造膜性 が向上し, 紙の繊維間に薄膜を形成しやすい。このために細孔分 布は小さい方へシフトし, 各種のバリヤー性能は向上する。また 皮膜自身蹯水基が表面に集まっているため発水性が高くなること が考えられる。このことは ESCA による皮膜の表面状態, 接触

角, 細孔分布の測定などから裏付けられる。

終りに発表を許可された会社当局に感謝します。

\title{
Interface Active Poly(vinyl alcohol)
}

\author{
Makoto Shiraishi***, Toshiyuki Akazawa and Koichi Kajitani \\ Research Laboratory, Kuraray Co., Ltd.; Sakazu, \\ Kurashiki-shi 710 Japan \\ ** Present address : Kumamoto Institute of Technology ; \\ Ikeda, Kumamoto-shi 860 Japan
}

The poly (vinyl alcohol) having both hydrophobic groups and hydrophilic groups has been prepared to endow water-solublity and interface activity. The modified poly(vinyl alcohol), derived from the terpolymer of hydrophobic monomer [Veova], hydrophilic monomer [Maleic anhydride or itaconic acid], and vinyl acetate, was soluble in water and gave an aqueous solution of low interfacial tention. Its film had water repelling property.

The vinyl acetate emulsion using the poly(vinyl alcohol) as a stabilizer was "high viscosity-low thixotropicity-high stability". The observation indicates that the modified poly(vinyl alcohol) has characters of both fully saponified and partly saponified ordinary poly(vinyl alcohol). It is noteworthy that the paper coated with the poly(vinyl alcohol) gave excellent barrier properties such as oil absorptivity, air permeability and also high surface strength. 